\title{
АДМИНИСТРАТИВНЫЙ РЕСУРС КАК ФЕНОМЕН РОССИЙСКОГО ИЗБИРАТЕЛЬНОГО ПРОЦЕССА
}

\section{А.Б. Воронцова, В.Б. Звоновский}

Наступление нового электорального цикла актуализировало научное обсуждение проблемы административного влияния на мнение и поведение избирателей. Данный феномен, получивший в литературе название административного ресурса, нередко сводят к нелегитимным методам воздействия властей предержащих на ход избирательной кампании. Думается, что такая оценка одностороння, и формы использования властных рычагов гораздо шире, нежели простое принуждение избирателя к тому или иному выбору или манипуляции с бюллетенями при подсчете голосов.

Существует также тенденция преувеличивать действенность административного ресурса, особенно на региональном уровне. Часто можно услышать, что результаты выборов в субъектах РФ во многом определяются позицией местных руководителей и, соответственно, на значимый успех может рассчитывать только та партия, которая опирается на их политические и административные возможности. Однако практика показывает, что такое представление ошибочно. Так, на парламентских выборах 1999 г. наибольшее число высших должностных лиц регионов было представлено в списке объединения "Наш дом Россия", которое получило лишь $1,19 \%$ голосов [см. Голосов 2000].

В настоящей работе мы попытаемся проанализировать административный ресурс как отражение российской политической реальности и рассмотреть варианты исчисления его объема. Под административным ресурсом будет пони-

114 маться совокупность имеющихся в распоряжении руководителей предприятий и/или территориальных образований (районов, городов) возможностей повлиять на мнение и поведение избирателей. Исследование выполнено преимущественно на материале Самарской области - одного из самых активных и представительных в политическом отношении регионов РФ.

\section{СУЩНОСТЬ И ФОРМЫ ПРОЯВЛЕНИЯ АДМИНИСТРАТИВНОГО РЕСУРСА}

Принято считать, что истоки административного ресурса (далее - A-ресурса) восходят к традиционной для патерналистски настроенных россиян готовности подчиняться “начальству”, которая создает “атмосферу, благоприятствующую реализации электоральных амбиций местных нотаблей” [Голосов, Шевченко 1999: 109]. И хотя рассуждения о влиянии “культурного наследия" на процессы в современной России нередко априорны, очевидно, что стереотипы недавнего прошлого не могут не сказываться на электоральном поведении нынешних российских граждан. Более того, есть основания полагать, что на постсоветское общество продолжает воздействовать тот комплекс социальных связей, который в значительной мере определял специфику общества советского.

По заключению исследователей, возможны два главных типа социальных связей. В первом случае речь идет об относительно развитом рынке социальной коммуникации, где информация проходит по нескольким независимым друг от друга каналам, не тождественным сетям социальной и, тем более, материальной зависимости. Чаще всего такая ситуация характерна для крупных городов. Здесь информация сравнительно свободно распространяется через

ВОРОНЦОВА Айгуль Болатовна, сотрудник Фонда социальных исследований; ЗВОНОВСКИЙ Владимир Борисович, кандидат социологических наук, президент Фонда социальных исследований (Самара). 
СМИ, а сети межличностного общения не замкнуты на определенную социальную группу, которая могла бы контролировать движение материальных ресурсов на данной территории.

Во втором случае распространение информации идет по ограниченному числу каналов, которые совпадают с каналами распределения материальных ресурсов. Такая картина типична для сельской местности и малых городов мира "плотных социальных сетей, где межличностные связи сами служат каналами, по которым политическая информация достигает индивидов" [Голосов, Шевченко 1999: 112]. Понятно, что в условиях, когда тот, кто сообщает, за кого нужно голосовать, совпадает с тем, кто выдает заработную плату, трудно говорить о реальной независимости избирателей.

В отличие от населения мегаполисов, жителей сел и небольших городов мало интересует партийная принадлежность кандидата. Ключевую роль в их электоральном выборе играет позиция местного “начальства". Если завтра партийные предпочтения “начальства” изменятся, то изменятся и предпочтения целых территорий*. И дело тут не в том, что в отношении сельских избирателей осуществляется большее насилие (например, информационное), чем в отношении городских. Просто их выбор реализуется в ходе социальной коммуникации, в которой задействовано гораздо меньше субъектов, нежели в крупном центре, чаще всего только два - избиратель и “начальство".

Наряду с плотностью социальных связей, на объем А-ресурса влияет и степень диверсификации источников благосостояния. Так, несомненно, этот ресурс имеет немалое значение в "молодых" городах с недавно сложившимся населением, занятым на одном или двух градообразующих предприятиях (типа Тольятти). Плотность социальных связей здесь сравнительно невелика (хотя и выше, чем в других крупных центрах), однако зависимость, пусть опосредованная, избирателей от деятельности одной, доминирующей в городе группы позволяет той оказывать существенное воздействие на их электоральное решение.

Разумеется, это не означает, что в полипромышленных крупных городах Аресурс полностью бездействен. Одним из каналов его реализации, причем доступным уже не только местным нотаблям, но и федеральной элите, могут быть СМИ, особенно электронные. Однако в данном случае он, безусловно, не столь эффективен, как на территориях с плотными социальными связями и ограниченными источниками материальных доходов.

Влияние A-ресурса может проявляться в четырех основных формах: (1) интриоризированная (внушенная, усвоенная) в ходе социальной коммуникации установка ("председатель нам столько хорошего о нем рассказывал”); (2) передача ответственности за выбор ("Кузьмич, голосуй за кого хочешь, мы тебе доверяем”); (3) “помощь” со стороны членов избирательной комиссии, подсказывающих гражданам, пришедшим на избирательные участки, за кого голосовать; (4) подкуп, запугивание, фальсификация бюллетеней и другие нелегитимные способы воздействия на результаты голосования. На практике эти формы административного влияния на электоральный процесс часто бывают слиты и используются одновременно, хотя и в разных пропорциях. Тем не менее мы не будем здесь останавливаться на четвертом варианте: он лишен исторической перспективы, поскольку заводит общество в тупик либо тоталитаризма и диктатуры, при которых запугивание и подкуп приобретают институциональный характер, либо “властной шизофрении”, когда правящие элиты соревнуются между собой в размере подтасовок. Что же касается первых трех вариантов, то у них, как показывает российский (и не только российский) опыт, есть все шансы сохраниться и в будушем.

Вопреки расхожим представлениям о “всемогуществе” А-ресурса, для его успешного использования требуются, как минимум, два условия. Во-первых,

* Именно это и произошло между двумя турами президентских выборов 1996 г., в частности, в Татарстане. 
внутри локальной административной элиты должно существовать согласие по поводу претендентов на выборные посты. Во-вторых, действия различных уровней административной иерархии должны быть скоординированы: федеральная элита должна так или иначе поддерживать позицию областной, областная - городской, городская - районной и так до тех пор, пока участник и организатор электорального процесса не совпадут в одном лице.

\section{ПОДХОДЫ К ОЦЕНКЕ ОБЪЕМОВ АДМИНИСТРАТИВНОГО РЕСУРСА}

При оценке объема А-ресурса мы исходим из того, что этот ресурс (в виде пакета голосов избирателей) существует вне зависимости от того, задействован ли он в данной конкретной ситуации или нет. В известном смысле можно сказать, что А-ресурс в той или иной форме присутствует всегда. При наличии внутриэлитного согласия он “работает" в пользу одного кандидата (списка) в рамках всего округа (региона). Если нотабли отдельных территорий в составе округа поддерживают разных кандидатов (списки) и в верхних эшелонах власти нет единства по этому вопросу, бенефициариями А-ресурса оказываются несколько кандидатов (списков). Но даже когда локальная элита расколота и избиратели, казалось бы, предоставлены сами себе, неправомерно говорить о полном отсутствии административного воздействия - ведь оно не столько изменяет электоральный выбор, сколько формирует его. По сути дела, А-ресурс - это степень готовности избирателя уступить свой политический выбор местному нотабилитету или, иначе, возможность сформировать выбор избирателя при более или менее выраженном согласии последнего. Если эта возможность по тем или иным причинам не реализуется, влияние Аресурса проявляется в падении явки. И напротив, высокая явка нередко свидетельствует об активном использовании А-ресурса.

\section{АДМИНИСТРАТИВНЫЙ РЕСУРС ПРИ ГОЛОСОВАНИИ ЗА ПАРТИЙНЫЕ СПИСКИ}

При голосовании по пропорциональной системе А-ресурс редко мобилизуется в поддержку конкретного партийного списка, ибо в этом случае участники электорального процесса (партии) по большей части не совпадают с его организаторами (органами исполнительной власти, занимающимися подготовкой списков избирателей, формированием избирательных комиссий, надзором за ходом предвыборной кампании). Иным образом складывается ситуация, когда кто-то из высших должностных лиц региона (особенно - его глава) становится одним из лидеров общенациональной партии. В этих условиях местная элита стремится максимально задействовать имеющийся у нее А-peсурс в интересах своего непосредственного начальника. Наиболее показательны в этом отношении “национальные" республики РФ, президенты которых либо напрямую входят в руководство федеральных партий, либо сотрудничают с ним (например, Татарстан и Башкортостан).

Идеальным для расчета объема А-ресурса был бы вариант, когда какая-то общенациональная партия, участвовавшая в одних выборах, получила бы поддержку местного нотабля на следующих, причем сроки проведения этих электоральных кампаний минимально отстояли бы друг от друга. Тогда разность между долями проголосовавших за данную партию на двух выборах можно было бы с известной долей приближения* рассматривать как показатель величины A-pecypca.

Избранный нами для анализа случай Самарской области менее удачен в этом плане: Союз правых сил, в руководство которого в 1999 г. вошел губернатор области К.А.Титов, был создан лишь незадолго до этого и в выборах 1995 г. не участвовал. Поэтому результаты голосования за СПС в 1999 г. мы сравнивали с общим объемом голосов, отданных в 1995 г. за партии демокра-

* Приблизительность подобных подсчетов обусловлена тем, что в них не учитывается естественная динамика поддержки партии, не зависящая от позиции местного руководства. 
тической ориентации*. Расчеты производились как по области в целом, так и отдельно по Новокуйбышевскому (151-му) округу**.

В 1995 г. в Самарской области за демократов проголосовали 16,9\% избирателей, а в 1999 г. за СПС - 22\%. Разница - 5,1\% - представляет собой Аpeсурс, т.е. тот пакет голосов, который обеспечил своей партии региональный лидер. Соответствующие цифры по Новокуйбышевскому округу $-11,1 \%$ и $22,6 \%$, а величина А-ресурса - 11,5\%. Тот факт, что во втором случае объем А-ресурса оказался существенно больше, безусловно, объясняется тем, что в рассматриваемый округ не входят крупнейшие промышленные центры области (Самара и Тольятти), на которые приходится 60\% ее населения, - ведь, как уже говорилось, жители крупных городов менее всего склонны перекладывать свой политический выбор на представителей локальной элиты.

Приведенные цифры характеризуют региональный уровень А-ресурса. Между тем логично предположить, что местные нотабли направляют на поддержку регионального босса не все имеющиеся в их распоряжении резервы. У них могут быть и собственные предпочтения, которые они также стремятся реализовать на выборах. Попробуем оценить объемы А-ресурса, задействованные на локальном уровне.

В 1995 г. в Новокуйбышевском округе за КПРФ проголосовали 31,5\% избирателей, в 1999 г. - 33,7\%. Рост поддержки составил 2,2\%, что соответствует общероссийским показателям $(2,1 \%)$. Однако на отдельных территориях округа масштабы колебаний оказались заметно выше. В двух сельских районах поддержка КПРФ сократилась приблизительно на $10 \%$, а в пяти административных единицах увеличилась, как минимум, на 5\%. Суммарная величина колебаний достигла порядка 9 тыс. избирателей, или 2,8\% от числа участвовавших в голосовании жителей округа. Вероятно, это и есть локальный уровень активизации А-ресурса***. Общий объем административного воздействия равняется, таким образом, $14,3 \%(11,5 \%+2,8 \%)$. Соотношение региональной и локальной величин А-ресурса (примерно 5 к 1) указывает на степень автономности местных элит от элиты областной.

Тем не менее картина, полученная с помощью подобных выкладок, вряд ли может быть полностью адекватной, ибо А-ресурс, безусловно, сыграл свою роль и на выборах 1995 г. В связи с этим нам следует рассмотреть и другие варианты расчета его объема. Одним из таких вариантов может быть выявление разницы в числе голосов, поданных за одного и того же кандидата в мажоритарном округе.

\section{АДМИНИСТРАТИВНЫЙ РЕСУРС ПРИ ГОЛОСОВАНИИ ЗА ОТДЕЛЬНЫХ КАНДИДАТОВ}

Для проведения такого рода вычислений обратимся к результатам голосования за первого секретаря обкома КПРФ В.Романова, баллотировавшегося в Госдуму по 151-му округу в 1995 и в 1999 гг. Разумеется, мы отнюдь не предполагаем, что в 1995 г. А-ресурс не использовался, а через четыре года его активизировали. Но поскольку есть основания считать, что та поддержка местной элиты, которую в 1995 г. получил Романов, впоследствии была переориентирована на его конкурента О.Дьяченко, разницу в электоральных показателях кандидата от КПРФ можно квалифицировать как задействованную долю А-ресурса.

\footnotetext{
* К данной категории были отнесены ДВР, “Яблоко”, “Вперед, Россия”, Блок Памфиловой, “Общее Дело", ПСТ, ХДС, Партия любителей пива, Блок независимых и блок ТТТ.

** 151 округ по выборам депутатов Госдумы является по своему составу смешанным сельско-городским: $49,6 \%$ приписанных к нему избирателей проживают в городах, преимущественно малых (самый крупный из городов округа - Новокуйбышевск), 50,4\% - в сельской местности и поселках городского типа.

*** Зафиксированные изменения не могли стать результатом естественной динамики предпочтений избирателей, ибо в таком случае они были бы примерно одинаковыми на всех территориях округа.
} 
В 1995 г. Романов набрал в округе 49,6\% голосов, а в 1999 г. $-45,1 \%$, т.е. численность его сторонников сократилась на 4,5\%. Причем, если в городах и несельскохозяйственных районах округа динамика почти отсутствует, то на сельскохозяйственных территориях она более чем значительна - 19,5\% (16,6 тыс. чел.). Иначе говоря, самые серьезные изменения произошли именно там, где, по нашей гипотезе, сушествуют наиболее благоприятные условия для реализации А-ресурса и где в 1995 г. население активнее всего голосовало за Романова (см. табл. 1). Территориальная структура данной трансформации свидетельствует о том, что причиной динамики явились не естественные сдвиги в предпочтениях избирателей, а административное воздействие.

Таблица 1

Территориальное распределение электоральной поддержки В.Романова на выборах 1995 и 1999 гг.

\begin{tabular}{|l|c|c|}
\hline & 1995 г. & 1999 г. \\
\hline Города & 49,9 & 49,1 \\
\hline Несельскохозяйственные районы & 41,9 & 43,1 \\
\hline Сельскохозяйственные районы & 58,9 & 39,4 \\
\hline Округ в целом & 49,6 & 45,1 \\
\hline
\end{tabular}

При более подробном анализе динамики голосования по разным территориям округа обращают на себя внимание заметные (около 10\%) подвижки в числе сторонников Романова в двух несельскохозяйственных районах - Кинель-Черкасском и Сергиевском. В первом случае полученная им доля голосов уменьшилась с 55,0\% до 44,6\%, во втором - выросла с $35,6 \%$ до 44,7\%. Не вызывает сомнений, что данные изменения (в сумме они затронули 4,5 тыс. избирателей) также обусловлены мобилизацией А-ресурса, не важно, происходила ли она в 1995 или 1999 г. Таким образом, можно утверждать, что переадресация административной поддержки отразилась на выборе 21,1 тыс. избирателей $(16,6+4,5)$, и, соответственно, общий объем перенаправленного А-ресурса достиг $6,7 \%$.

Представляется, однако, что и такой вариант расчета А-ресурса не позволяет оценить его предельные возможности. В ряде случаев поддержка кандидата местной властью могла остаться неизменной, а значит, эти составляющие А-ресурса были нами упущены.

\section{АДМИНИСТРАТИВНЫЙ РЕСУРС НА ГУБЕРНАТОРСКИХ ВЫБОРАХ}

Еще одним показателем объема А-ресурса может служить разность между долями голосовавших за национально-патриотическую оппозицию (ЛДПР, КПРФ и ее союзников), с одной стороны, и ее кандидата на выборах губернатора - с другой. Данная формула строится на двух допущениях. Первое из них - о возможности пренебречь действием иных видов ресурсов, прежде всего личностного. Выведение его за скобки представляется вполне оправданным, поскольку в основании нашей гипотезы лежит не сам по себе высокий уровень поддержки действующего губернатора, а отсутствие корреляции между голосованием по партийным спискам и по отдельным кандидатам. Отсутствие такой корреляции указывает на малую погруженность соответствующей локальной общности в политическую жизнь и, тем самым, на высокую степень воздействия мнения политической элиты на поведение населения. В подобной ситуации личностный ресурс является результатом согласия местной политической элиты, т.е. одной из составляющих А-ресурса. Правда, бывают случаи, когда личностный ресурс заметно влияет на поведение избирателей (например, при рас- 
коле местной элиты), однако его воздействие очевидным образом ограничено территориально.

Второе допушение связано с пренебрежением разницей в активности избирателей в двух электоральных случаях (в думских выборах 1995 г. приняли участие $69,13 \%$ зарегистрированных в округе избирателей, а в губернаторских 1996 г. - лишь 59,53\%). Как свидетельствуют проводившиеся в последние годы исследования, склонность к абсентеизму демонстрируют преимущественно сторонники “реформаторов”. Поэтому на выборах с низкой явкой увеличивается доля “зависимых" от власти, а значит - и относительный объем Apeсурса, исчисленный в процентах от числа принявших участие в голосовании. Мы можем пересчитать его с учетом активности избирателей, но, как будет показано ниже, величина отклонения невелика.

В 1995 г. на выборах в Госдуму оппозиционные партии (КПРФ, ЛДПР Аграрная и ряд более мелких) набрали в Новокуйбышевском округе 59,74\% голосов, а в 1996 г. на выборах губернатора кандидат от КПРФ В.Романов - 33,80\%, т.е. разрыв составил около 26\%. Согласно нашей гипотезе, этот разрыв можно квалифицировать как объем задействованного А-ресурса. Хотя на изменения в уровне поддержки оппозиции и ее кандидата повлияли все виды доступных акторам ресурсов, в т.ч. личностные и партийные, в условиях преимущественно сельского округа основную роль, вне сомнения, сыграл именно А-ресурс. В пользу такого заключения говорят, в частности, данные по территориям с различной поселенческой структурой. Так, в Самаре за Романова проголосовали $34 \%$ пришедших на избирательные участки, а годом раньше за оппозиционные партии - 37\%. В свою очередь, в малых городах 151-го округа соотношение между этими показателями - 37\% и $45 \%$, а в сельских районах - $31 \%$ и $64 \%$, соответственно. Иными словами, при количественной оценке объема А-ресурса выбранным нами способом он дает максимум именно там, где теоретически наиболее значим, и наоборот. Отсюда следует, что он вполне адекватно отражает сущностные характеристики изучаемого феномена и вполне пригоден для его количественного измерения.

Теперь попробуем учесть влияние на рассматриваемый показатель разницы в активности избирателей. Для решения этой задачи мы сначала подсчитаем абсолютное число избирателей, ощутивших на себе воздействие А-ресурса на выборах губернатора, а затем посмотрим, какую долю оно составляет от числа участников голосования 1995 г. Результат равен 22\%, или порядка $85 \%$ от вычисленного без учета разницы в активности.

Самые значительные изменения претерпела активность горожан, ослабление их стремления повлиять на распределение сил во властных структурах в два с лишним раза превысило аналогичную тенденцию среди сельских избирателей (11\% и 5\%, соответственно). Это подтверждает наше предположение, что использование А-ресурса сказывается не только на результатах голосования, но и на участии в нем. Измерение колебаний в объеме А-ресурса в зависимости от уровня явки позволяет проследить его влияние на активность избирателей.

Эффективность А-ресурса не всегда одинакова. Одним из факторов ее снижения может стать воздействие ресурса личностного. Так, в Новокуйбышевске, где Романова хорошо знали, объем перенаправленного в пользу его соперника А-ресурса оказался существенно меньше, чем по округу в целом (около 11\%). И хотя нельзя исключить, что в Новокуйбышевске какая-то часть А-ресурса "работала” на Романова, наличие у последнего мощного личностного ресурса, несомненно, повлияло на итоги выборов.

Итак, мы видим, что в наибольшей степени А-ресурс бывает задействован на выборах, в которых лично участвует руководитель региона. Однако и в таких случаях влияние "начальства" на предпочтения избирателей не беспредельно. Даже в столь открытом для подобного влияния округе, как Новокуйбышевский, объем А-ресурса не смог превысить $22 \%$. 


\section{АДМИНИСТРАТИВНЫЙ РЕСУРС В УСЛОВИЯХ РАСКОЛА ЭЛИТ}

До сих пор мы анализировали действие А-ресурса в ситуации более или менее выраженного консенсуса среди местных элит. При отсутствии такого консенсуса А-ресурс используется несогласованно или не используется вовсе.

В первом случае элиты разных районов ориентируют избирателей на поддержку конкурирующих сил. В результате возникает серьезная территориальная дифференциация в распределении голосов, поданных за отдельные партии (кандидатов). Так, в декабре 1999 г. СПС поддержали 24\% жителей Самары и $50 \%$ - Клявлинского района области; ОВР получила $40 \%$ голосов в Уфе и $5 \%$ - в Самаре, и т.д.

Во втором случае вследствие острой борьбы внутри местного "начальства" (обычно на уровне территориальных единиц) элита утрачивает контроль над ситуацией, и избиратели оказываются предоставлены сами себе. В таких условиях население, как правило, начинает поддерживать кандидатов, демонстративно противостоящих действующей администрации. Так, на думских выбоpax 1999 г. в Тольятти, где разгорелась жаркая схватка между представителями различных элитарных группировок, победителем стал руководитель рабочего профсоюза АвтоВАЗа А.Иванов. В 1997 г. на выборах мэра Самары четвертое место занял маргинальный политик О.Киттер.

В зависимости от глубины раскола локального нотабилитета происходит частичная или полная демобилизация административного ресурса. Рассмотрим эти два варианта подробнее.

\section{ЧАСТИЧНАЯ ДЕМОБИЛИЗАЦИЯ АДМИНИСТРАТИВНОГО РЕСУРСА}

Как уже отмечалось, успешное использование А-ресурса возможно лишь при наличии конечного звена, т.е. администрации, формирующей избирательные комиссии и осуществляющей надзор за ходом предвыборной кампании. В свою очередь, этому звену должна поступать надежная и согласованная информация о настроении элит более высокого уровня. Если такая информация носит противоречивый характер, или мнения на верхних ступенях иерархии разделились, или власть устранилась от определения своей позиции, местные нотабли действуют по собственному усмотрению. Вследствие этого влияние A-ресурса может быть диверсифицировано и трудноуловимо. Именно такая ситуация сложилась на внеочередных выборах губернатора Самарской области*, состоявшихся 2 июля 2000 г.

Согласно официальным данным, в областном центре Титов набрал 50,03\% голосов - меньшая доля избирателей проголосовала за него лишь в трех из 10 городов и в шести из 27 сельских районов области. Другими словами, в месте сосредоточения политической и хозяйственной элиты области экс-губернатор получил чуть ли не худшие результаты. Более того, именно в центральных районах города (Ленинском и Октябрьском) доля сторонников Титова составила менее половины. Показательно, что на проходивших в тот же день выборах депутатов городской Думы в этих районах победили два оппозиционных мэру города** кандидата.

В ходе опроса жителей Самары, проведенного 26-28 июня 2000 г., выяснилось, что популярность Титова среди руководителей среднего звена почти не превышает среднюю по городу (соответственно, 56\% и 54\%). Иначе говоря, даже за несколько дней до голосования в кругу хозяйственной и управленческой элиты не сложилось единого мнения относительно кандидатуры губернатора, и эта группа не могла стать источником поддержки лидера. Столь же неоднозначной оказалась и позиция представителей интеллектуальной элиты города, которые, по-видимому, перестали видеть в Титове наиболее подходя-

\footnotetext{
* Потерпев поражение на президентских выборах 2000 г., К.Титов подал в отставку и с поста губернатора, однако принял участие в новой губернаторской “гонке".

** Мэр Самары Г.Лиманский публично поддержал кандидатуру Титова на выборах губернатора области.
} 
щую для себя фигуру. Если еще в начале июня в его пользу высказывались $60 \%$ выпускников вузов, то к концу месяца - только $50 \%$.

Не менее сложной была обстановка во втором по величине городе области - Тольятти. За пять дней до выборов здесь были готовы поддержать недавнего губернатора 59\% определившихся горожан и лишь 50\% руководящих работников. Утрата монопольного влияния на местную хозяйственную элиту немедленно отразилась на электоральных результатах: Титов набрал в Автограде немногим более половины голосов (52\%). В свою очередь, в Сызрани, где "начальство" сохранило лояльность бывшему главе области (82\% поддержки), он добился впечатляющего успеха (около 64\% голосов).

Надежные данные относительно предпочтений руководителей среднего звена других городов, а также сельских районов, отсутствуют (вследствие малого объема подвыборки), однако о настроениях местных элит можно судить по результатам выборов главы соответствующей административной единицы, проходивших одновременно с губернаторскими*. О наличии внутриэлитного согласия правомерно говорить в том случае, если на этих выборах победитель выявился в один тур, причем уровень его отрыва от соперников свидетельствует о степени согласия.

В городах, где доля проголосовавших за победителя местных выборов превышала 75\%, в пользу Титова высказались 54-64\% избирателей, а там, где она составляла $50-60 \%,-$ от $40 \%$ до 55\%. Тем не менее прямой корреляции между согласованностью действий местных элит и электоральными показателями Титова не прослеживается: в Похвистнево, вновь избранный мэр которого получил $85 \%$ голосов, лидер губернаторской гонки набрал лишь 53,8\%, т.е. меньше, чем в Кинеле (55\%), где разброс мнений внутри элиты был гораздо заметнее.

Сельские районы мы разделили на три группы. В первую включены те из них, где действующий глава исполнительной власти завоевал в первом туре свыше 65\% голосов. Очевидно, что степень внутриэлитного согласия здесь очень велика. Во вторую группу вошли районы, в которых глав администрации поддержали 49-65\% избирателей. В этих районах элита не сумела определиться со своим выбором. И, наконец, к третьей группе отнесены районы, где потребовался второй тур, а также Большечерниговский район, где инкумбент проиграл уже в первом туре.

В первой группе районов доля голосов, поданных за Титова, составила $58,8 \%$, во второй $-54,6 \%$, в третьей $-55,8 \%$. Иначе говоря, расхождения внутри сельской элиты по вопросу о будущем главе местной администрации не обязательно означают отсутствие согласия относительно руководителя области в целом. Вместе с тем дифференциация районов по уровню поддержки нынешнего губернатора существовала и была значительной - от 75\% в Елховском районе до $39 \%$ в Клявлинском.

Два из шести районов, где за Титова высказалось менее половины жителей, входят в округ, депутатом от которого являлся Г.Звягин, также баллотировавшийся на пост губернатора и занявший третье место. В Богатовском районе за этого кандидата, получившего по области чуть более $9 \%$ голосов, проголосовали $32 \%$ избирателей, а в Нефтегорском - $19 \%$. Двумя с половиной годами раньше, на выборах депутатов губернской Думы, Звягин набрал в Богатовском районе $73 \%$ голосов, а в Нефтегорском - 43\%. Причем в последнем случае он был вторым после действовавшего районного главы (48\%), которого на выборах руководителя района, проходивших одновременно с губернаторскими, поддержали 52\% избирателей. Очевидно, что согласие по поводу кандидатуры главы администрации было здесь оборотной стороной поддержки Звягина.

Как видим, степень электорального успеха Титова в сельских районах лишь отчасти зависела от согласия внутри местной элиты. И хотя в подавляющем

* K сожалению, при таком подходе вне поля нашего зрения остается Октябрьск, где за Титова было подано 78,8\% голосов: выборы мэра и членов городского Совета там состоялись в марте 2000 г. 
большинстве районов такое согласие “работало” в пользу лидера, в случае, если местная элита была связана с его конкурентами, консенсусным могло стать решение голосовать “не за Титова". В некоторых ситуациях местное “начальство”, по тем или иным причинам вынужденное учитывать интересы соперников нынешнего губернатора, направляло свой А-ресурс на поддержку нескольких кандидатов. В этих регионах раскола элит удалось избежать, но ценой его локализации на уровне участников губернаторской гонки.

Наименьшую поддержку победитель получил там, где нотабли полностью утратили контроль над ситуацией. Показательно, что в этих районах борьба между претендентами на пост местного лидера приобрела партийно-политическую окраску, как, например, в Клявлинском и Красноармейском районах, где во второй тур местных выборов вышли представители КПРФ. Иначе говоря, идеологическое противостояние возникает лишь при отсутствии единства внутри локального “начальства", когда другие и, вероятно, более сильные регуляторы электорального выбора дают сбой.

\section{ПОЛНАЯ ДЕМОБИЛИЗАЦИЯ АДМИНИСТРАТИВНОГО РЕСУРСА}

При ослаблении административного воздействия вследствие раскола местной элиты может начать набирать силу так наз. "протестное голосование", которое, как правило, принимает форму либо голосования против всех, либо поддержки "несистемных" кандидатов*. Подобные кандидаты мобилизуют в свою пользу те категории граждан, которые в иных условиях не пришли бы на избирательные участки. В случае низкой явки (а, как уже говорилось, падение эффективности А-ресурса обычно сопровождается уменьшением таковой) данная стратегия может оказаться весьма успешной. Так, при активности избирателей менее $40 \%$ каждые следующие $2 \%$ дают прирост поддержки примерно на 5\% при одновременном относительном снижении электоральных показателей соперников.

122 Именно такой сценарий был реализован во время кампании 1997 г. по выборам мэра Самары, когда мало кому известный “новый русский”, спонсор ряда акций местных коммунистов, бывший милиционер, владелец сыскной конторы, шести коллекционных автомобилей и еженедельника "Алекс" О.Киттер сумел добиться значительного успеха, заняв по результатам первого тура четвертое место. Напомним, что эти выборы проводились в связи с тем, что прежний мэр О.Сысуев был назначен вице-премьером федерального правительства**.

Покидая пост, Сысуев, который в узких кругах высказывался в пользу главы Ленинского района Самары А.Белоусова, под давлением собственного аппарата представил городу в качестве своего потенциального преемника заместителя мэра А.Афанасьева. И хотя никакой реальной поддержки, особенно публичной, Сысуев ему не оказал, слово уходящего мэра, безусловно, повлияло на продвижение кандидатуры Афанасьева в сознании горожан. Третьим претендентом на пост градоначальника стал Г.Лиманский - тогда заместитель председателя губернской Думы.

Локальная элита не смогла однозначно определиться со своим выбором и раскололась на три лагеря. Даже внутри сысуевской команды не было единства. Небольшая, но значимая ее часть поддержала Белоусова. Не выразила сколько-нибудь четкой позиции и областная администрация.

\footnotetext{
* “Несистемными” мы называем кандидатов, которые критично относятся к деятельности как правящей группы, так и сложившейся оппозиции. Их социальной опорой выступают группы, негативно настроенные по отношению к системе власти как таковой и видящие в ее ликвидации путь к решению общественных проблем.

** Предыдушие выборы главы города состоялись 1 сентября 1996 г. В первом же туре за О.Сысуева, занимавшего эту должность с декабря 1991 г., проголосовали более $72 \%$ избирателей. Из других четырех кандидатов, участвовавших в выборах, двое (А.Белоусов и Г.Лиманский) набрали по $11 \%$ голосов, а суммарный результат двух оставшихся составил менее $2 \%$.
} 
26 июня 1997 г. в голосовании приняли участие 39,6\% жителей города. А.Афанасьев получил $28,4 \%$ голосов, Г.Лиманский - 20,4\%, А.Белоусов $15,1 \%$, О.Киттер - 14,7\%, первый секретарь горкома КПРФ М.Маслянцев $9,5 \%$ голосов. Остальные собрали в сумме менее $7 \%$.

Еше за полтора-два месяца до голосования политический вес О.Киттера был близок к нулю. Этот “несистемный” кандидат пользовался поддержкой лишь небольшого по численности и влиянию местного отделения Республиканской партии и нескольких радикальных группировок (Партия диктатуры пролетариата, “Гражданская инициатива"). Правда, по некоторым данным, свое вступление в предвыборную гонку Киттер согласовал с Лиманским. Во всяком случае, после объявления результатов первого тура он призвал избирателей голосовать именно за него.

Команда Киттера с самого начала четко очертила линию противостояния: “мы - они”, направив основной удар против политики администрации Сысуева и рисуя трех главных претендентов на пост мэра ее продолжателями. Раздававшаяся на улицах и в общественном транспорте газета (она издавалась Киттером лишь во время кампании) подчеркивала радикальную оппозиционность кандидата, отказавшегося как от услуг "Роспечати", так и от распространения рекламных материалов через почтовые ящики. Кампания проходила под лозунгом “Не голосуйте за трех толстяков!”, где удачно обыгрывалась физическая и “административная" конституция Афанасьева, Лиманского и Белоусова.

"Антисистемная" направленность кампании позволила Киттеру “расшевелить” избирателей, которые обычно игнорируют выборы и политику вообще, настроенных против власти как таковой, под каким бы идеологическим прикрытием (“коммунисты”, “демократы”, “патриоты” и т.д.) та ни выступала. Об этом свидетельствует тот факт, что в округах, где Киттер добился наибольшего успеха, активность избирателей по сравнению с прошлыми выборами мэра заметно возросла. В Кировском районе (19,5\% поддержки) явка увеличилась на $8,4 \%$, в Промышленном $(15,2 \%)$ - на $5,9 \%$, в Советском $(16,1 \%)-$ на 2,8\% (см. табл. 2). Показательно, что в Ленинском районе города, где явка осталась практически прежней, “Киттер-сюрприз” не состоялся $-10,1 \%$. Примерно такая же ситуация сложилась в Куйбышевском районе: рост активности $-0,8 \%$, результат Киттера $-10,0 \%$.

Таблица 2

Выборы мэра Самары: явка и результаты

\begin{tabular}{|c|c|c|c|c|c|c|c|c|c|}
\hline \multicolumn{10}{|c|}{ Районы } \\
\hline & $\begin{array}{l}\text { Железно- } \\
\text { дорожный }\end{array}$ & $\begin{array}{c}\text { Куйбы- } \\
\text { шевский }\end{array}$ & $\begin{array}{l}\text { Ленин- } \\
\text { ский }\end{array}$ & $\begin{array}{c}\text { Октябрь- } \\
\text { ский }\end{array}$ & $\begin{array}{l}\text { Самар- } \\
\text { ский }\end{array}$ & $\begin{array}{l}\text { Совет- } \\
\text { ский }\end{array}$ & \begin{tabular}{|c} 
Киров- \\
ский
\end{tabular} & $\begin{array}{l}\text { Красно- } \\
\text { глинский }\end{array}$ & $\begin{array}{c}\text { Промыш- } \\
\text { ленный }\end{array}$ \\
\hline \multicolumn{10}{|c|}{ Активность избирателей (в \%) } \\
\hline 1.09. 1996 г. & 35,47 & 39,08 & 41,99 & 37,81 & 36,92 & 36,91 & 31,12 & 35,02 & 31,75 \\
\hline 29.06.1997 г. & 38,99 & 40,30 & 41,98 & 40,46 & 36,42 & 39,67 & 39,53 & 36,41 & 37,73 \\
\hline 13.07.1997 г. & 40,03 & 44,64 & 40,14 & 40,23 & 39,67 & 44,73 & 42,20 & 40,74 & 40,13 \\
\hline \multicolumn{10}{|c|}{ Доля голосов (в \%), поданных 29 июня 1997 г. за: } \\
\hline Лиманского & 16,20 & 22,80 & 12,84 & 17,30 & 16,29 & 20,45 & 18,81 & 21,17 & 26,82 \\
\hline Афанасьева & 33,44 & 28,11 & 32,76 & 31,35 & 35,32 & 29,87 & 26,52 & 24,87 & 24,52 \\
\hline Белоусова & 15,28 & 18,82 & 24,66 & 16,96 & 16,90 & 12,92 & 13,46 & 15,87 & 13,12 \\
\hline Киттера & 14,40 & 10,01 & 10,06 & 11,91 & 11,57 & 16,09 & 19,48 & 8,98 & 15,23 \\
\hline \multicolumn{10}{|c|}{ Доля голосов (в \%), поданных 13 июля 1997 г. за:: } \\
\hline Лиманского & 45,19 & 33,03 & 50,75 & 46,19 & 43,75 & 41,72 & 34,11 & 33,29 & 31,42 \\
\hline Афанасьева & 47,64 & 59,37 & 41,45 & 46,01 & 49,61 & 50,62 & 58,34 & 59,45 & 61,88 \\
\hline
\end{tabular}


Продолжая оставаться значимой фигурой в предвыборной борьбе, Киттер повлиял и на конечные результаты выборов. Его призыв к избирателям поддержать во втором туре кандидатуру Лиманского был услышан: как показывают приведенные в таблице данные, в районах, где Киттер пользовался наибольшей популярностью (например, в Кировском и Советском), во втором туре явка не только не уменьшилась, но даже возросла. Это в немалой степени предопределило победу нынешнего мэра.

Приведенный выше пример подтверждает высказанную нами гипотезу о возможности полной демобилизации А-ресурса в условиях раскола элит. Именно это и позволило “несистемному” кандидату добиться неожиданного успеха, опершись на критически настроенных по отношению к существуюшей системе власти избирателей. Избиратели указанного типа очень подвижны в своих настроениях: от глухой пассивности они быстро переходят к эйфории, и наоборот. Поэтому данная часть электората не может быть постоянно активной. Скорее всего, она вернется в пассивное состояние и вновь будет ожидать кандидата, способного доказать ей свою “антисистемность".

Итак, в условиях раскола элит серьезные шансы получают те кандидаты, которые позиционируют себя в качестве оппозиции действующей системе власти в целом. В подобной ситуации мобилизация А-ресурса оказывается весьма затруднительной, а его использование - неэффективным.

$$
* * *
$$

Проведенный анализ, как нам кажется, проясняет природу и сущность административного ресурса. В основе этого феномена лежит система социальных сетей, сложившаяся в селах и малых городах России. Минимальная диверсификация системы социальной коммуникации, присущая небольшим населенным пунктам, не позволяет индивиду сформировать собственный политический выбор и побуждает его переложить ответственность за этот выбор на “начальство". Доля передающих свой выбор местному руководителю и определяет объем А-ресурса на данной территории. Иными словами, А-ресурс есть не насилие над избирателем, а скорее выражение согласия последнего на отчуждение его политического выбора. По мере усложнения социальной коммуникации готовность индивидов к принятию самостоятельных решений возрастает. В результате усиливается значение политических, групповых и личностных предпочтений, а мера административного воздействия сокращается.

Исследование показало, что эффективность А-ресурса во многом зависит от степени внутриэлитного согласия. В случае глубокого раскола элиты часть ориентированных на мнение нобилитета избирателей отказывается от голосования. Одновременно повышается активность тех, кто, будучи настроен против системы власти как таковой, традиционно воздерживался от участия в выборах, что увеличивает шансы на победу “несистемного" кандидата.

Предложенные подходы к вычислению объема А-ресурса дают возможность не только анализировать уже прошедшие выборы, но и прогнозировать результаты будущих. Хотелось бы надеяться, что это поможет вывести феномен А-ресурса из сферы политических фантазий и мифов.

Голосов Г.В. 2000. Губернаторы и партийная этика. - Pro et Contra, том 5, зима.

Голосов Г.В., Шевченко Ю.Д. 1999. Независимые кандидаты и зависимые избиратели: влияние социальных сетей на электоральную политику в России. - Полис, № 4. 